\title{
No Longer. Not Yet. The Promise of Labour Law
}

\section{David Mangan}

To cite this article: David Mangan (2015) No Longer. Not Yet. The Promise of Labour Law, King's Law Journal, 26:1, 129-150, DOI: 10.1080/09615768.2015.1035131

To link to this article: https://doi.org/10.1080/09615768.2015.1035131

央 Published online: 23 Jun 2015.

Submit your article to this journal

WII Article views: 1677

View Crossmark data $\asymp$ 


\title{
No Longer. Not Yet. The Promise of Labour Law
}

\author{
David Mangan*
}

\section{INTRODUCTION}

No longer. Not yet. These two phrases summarise the promise of British labour/employment law. ${ }^{1}$ There have been fleeting moments of positive steps towards employment protections. And yet, the focus of efforts remains to improve the present. Labour law has become a source of lament insofar as its contemporary form resembles little from a few decades prior and, simultaneously, offers tantalising bits of hope for better days. There have been a number of publications pronouncing a pessimistic state for labour law. ${ }^{2}$ This perspective originates in a view of the discipline that expects more of contemporary worker protections and reflects back on the 1980s as a period of tremendous decline on this account.

Economic duress is a theme that runs through the collective-dominant to the individual-dominant periods of labour law. Complaints about economic duress (the perceived unfair influence of trade unions by way of industrial action) were part of the movement that brought about the decline in collective labour law in the 1980s. An amended form of the argument is being used again today. Illustrating the contemporary usage, employment tribunal procedure reforms (such as the introduction of fees for claims) passed in and around 2013 were premised on the idea of improving the economy (perhaps a first for economic stimulus). Threatening to continue the 'not yet' era of labour law, this example demonstrates how the imperative of commercial

* Osgoode Hall Law School. I am grateful to Professor Tonia Novitz for her remarks on this work. Errors and omissions are my own. Professor Andrew Huxley (SOAS) passed away during the preparation of this article. His witty advice will be greatly missed. Email: dmangan@osgoode.yorku.ca

1 Even the name of the discipline signifies division: where labour law is viewed as containing the historical and employment the more current aspects. Labour law will be used to encompass the law relating to those who engage in paid work; that is the law pertaining to the labour of the individual. The term includes both the collective and the individual: Lord Wedderburn, 'Deregulation and Labour Law in Britain and Western Europe' (1988-89) 6 Hofstra Labor Law Journal 135, 137.

2 The premise of unrealised potential may be applied to the UK as well as other jurisdictions. See for example, C Barnard, S Deakin and GS Morris (eds), The Future of Labour Law: Liber Amicorum Bob Hepple Q.C. (Hart Publishing 2004); G Davidov and B Langille (eds) The Idea of Labour Law (Oxford University Press 2011). 
viability not only dictates labour regulation, but may also prove to continue the area's decline. Although the hope of better days remains alive, it is in a muted form.

\section{NO LONGER}

The characterisation of labour law remains an obstacle. One moment that may signal a point of no return to the days of greater union influence may be the foreword by thenPrime Minister Tony Blair in Fairness at Work. He wrote: 'There will be no going back. The days of strikes without ballots, mass picketing, closed shop and secondary actions are over.' ${ }^{3}$ Though a rhetorical characterisation of labour law, this quotation remains instructive for it conveys how labour law has been received: a discipline about disruption to business.

The decline of the collective in labour law has been extensively engaged. These writings chart decay in trade unions' role in contemporary Britain. Today, looking for positives, it may be said that unions play a practical role in streamlining discussions surrounding the workforce: providing employers with an efficient means of communicating with workers and facilitating workplace changes. ${ }^{4}$ The role measures the shift from the social function of labour law to a focus on its utility in supporting economic goals. Here is the division representing the contrast between no longer and not yet. Labour law remains, for employee-side practitioners and a large academic cohort, an area concerned with 'struggle" amongst social groups. However, as defined by governments of differing political affiliations, labour law is conceived of as a support to economic growth.

The deterioration of trade union membership (and influence), ${ }^{6}$ sitting at about $25.6 \%$ as of May 2014, ${ }^{7}$ in the UK ran concurrently with the rise of economic concerns becoming the guiding force in decision-making. Unions themselves were viewed as obstacles to desired economic growth. Trade unions, it was alleged, had 'abused' their power through industrial action that harmed 'innocent third parties' and consumers. ${ }^{8}$

3 Fairness at Work (Cm 3968) (TSO 1998), 2.

4 The information and consultation aspects of the Trade Union and Labour Relations (Consolidation) Act 1992 are one example.

5 B Hepple QC, 'Factors Influencing the Making of Labour Law' in G Davidov and B Langille (eds) The Idea of Labour Law (Oxford University Press 2011) 30, 42.

6 The high-water mark was 1979 when there were 13 million members. From 1980 to the mid-1990s there was a steady decline in membership. Since that time, the percentage of the unionised workforce has largely shrunk (though it increased in 2010-11) and sits at about 6.5 million, a drop of 6000 members or $0.1 \%$ : Department for Business Innovation \& Skills (BIS), Trade Union Membership 2013 (London: BIS, 2014) [Trade Union Membership 2013], 5.

7 'This is the lowest rate of trade union membership recorded between 1995 and 2013. Over this period, the proportion of employees who were trade union members in the UK has decreased around 7 percentage points, from 32.4 per cent in 1995': Trade Union Membership 2013 (n 6) 5. It should be noted that there has been an increase in membership in the private sector, as of May 2014, to about 2.6 million members.

8 B Simpson, 'British Labour Relations in the 1980s: Learning to Live with the Law' (1986) 49 Modern Law Review 796, 810. 
Legislative reforms were passed to undercut the force unions could possibly have. The 'traditional public policy of encouraging the spread of collective bargaining' was found to be incompatible with a 'more market-oriented analysis of economic problems'. 'This topic has been the subject of much discussion and will not be repeated here. It is remarkable, nevertheless, how successful the strategy continues to be. It tapped into something of a human bias: as a result of others, the individual is being held back from making progress. Trade unions became the quintessential example.

Democratising trade unions was another touchstone. Looking back, democratisation arguments were the precursor to individualistic aims. The increasing role of government in labour relations regulation has led to the pre-eminence of the individual contract of employment as the embodiment of mutual obligations between employer and worker, a setting described as encouraging 'forms of marginal employment which are subject to a minimum of protective rights for workers, as well as direct erosion ... of rights' ${ }^{10}$ Criticism remains non-partisan, extending beyond the Conservatives of the 1980s. Noting the 'public relations verbiage' found in Fairness at Work, one may point to the thennewly elected Labour party's document as lacking 'the necessary commitment to collective bargaining as an "industrial relations good". ${ }^{11}$ Despite the addition of a national minimum wage, one commentator wrote with dismay of Labour's continuation of the economic foundation for employment regulation: the minimum wage is heavily qualified by the government's evident deference to the view that social rights for workers are a part of employers' labour costs which must be minimised in the interests of maintaining their ability to compete in increasingly global markets'. ${ }^{12}$

In assessing the decline of collective laissez-faire in the 1980s, Professor Collins characterised the period as a 'productive disintegration'. ${ }^{13} \mathrm{He}$ applauded Professors Davies and Freedland ${ }^{14}$ for providing a means to engage with the individual rights of employment law. Furthermore and most prominently, the 1980s legislation should be viewed not as 'a blunt attack on collective bargaining and trade unions, but a new anti-inflation strategy.' ${ }^{15}$ The conclusion: labour law must be situated within the context of macroeconomic policies. ${ }^{16}$ Now, economic policy dominates discussions. The move to a macroeconomic focus has compelled consideration of the workforce as part of one grouping (collective) - the workforce of the company that is England competing amongst global entities. From this notion key terms such as efficiency and

Ibid, 800, where Simpson's review cited P Davies and M Freedland, Kahn-Freund's Labour and the Law (Stevens, 3rd edn 1983).

$10 \quad$ Ibid, 816.

11 B Simpson, 'Fairness at Work' (1998) 27 Industrial Law Journal 245, 248.

12 Ibid, 252.

13 H Collins, 'The Productive Disintegration of Labour Law' (1997) 26 Industrial Law Journal 295, 303.

14 P Davies and M Freedland, 'Labour Law and the Public Interest - Collective Bargaining and Economic Policy' in Lord Wedderburn and WT Murphy (eds), Labour Law and the Community: Perspectives of the 1980s (Institute of Advanced Legal Studies 1982) 13, 14.

15 Collins (n 13) 303.

16 Ibid. 
productivity originate. It has been asserted that the 'collectivist interpretation of the system of industrial relations' has been unreceptive to considerations of individual rights. ${ }^{17}$ And yet, nuance appears to be the key point: collectivists were highly suspicious of an individualist system that had freedom to contract as its underlying ethos. ${ }^{18}$ This concern, retrospectively, was not unfounded. The greater success achieved by trade unions in relation to employment protections must be a testament to the power of the collective over that of the individual. Usurpation of individual rights was not the aim. Instead the collective was the better strategy to achieve the end goal of greater employment protection and increased remuneration packages (whether that be monetary gains or other improvements). And still, the success of collectives was eschewed because it was perceived to have come at the expense of the country's economic strength.

The judiciary played an integral role in the encompassing force of the term economic duress. It did not accept that there could be 'an area of legitimate industrial conflict within which the restraints of the common law should not apply. ${ }^{19}$ 'Privileges ${ }^{20}$ (language employed by Friedrich von Hayek) has been aptly used as a descriptor of what unions sought according to the judiciary: trade unions were seeking privileged status to undertake activities which the economic minds of the judiciary deemed harmful. The House of Lords decision in Universe Tankships Inc. of Monrovia v International Transport Workers Federation ${ }^{21}$ offered a convenient illustration. The case concerned the Federation's campaign to 'black-flag' ships flying 'flags of convenience'; a means for shipowners to avoid employment protections for crewmembers. The court refused to look at this as a case pertaining to the terms and conditions of employment for seafarers; that is as a labour dispute (the golden formula being inapplicable). ${ }^{22}$ The Federation conceded that its campaign constituted economic duress. In essence, the concession was that the Federation's work to protect members fell foul of one of the few limitations English contract law imposes upon parties. ${ }^{23}$ The concession remains important because duress requires particular facts to establish the case. Furthermore, duress claims can often become mixed in with arguments (often made by the academic community) regarding a need for good faith in English contract law, something of a hotly contested area to which no resolution seems foreseeable. ${ }^{24}$

17 Ibid, 304.

18 Beyond legislation, the 'residue' of English law is the common law and its premise of freedom of contract separates British labour law from other systems: Wedderburn (n 1) 137.

19 B Simpson, 'A Not So Golden Formula: In Contemplation or Furtherance of a Trade Dispute After 1982' (1983) 46 Modern Law Review 463, 465.

$20 \quad$ Ibid, 466.

21 [1982] 2 WLR 803 [Universe Tankships].

22 Simpson noted the uncertainty as to what the court was saying in Universe Tankships: Simpson (n 19), 468.

23 Duress (along with misrepresentation and undue influence) remains a concept to which the English common law points when it is criticised for having no duty of good faith.

24 Some momentum to the argument for good faith obligations in English contract law has arisen from the decision in Yam Seng Ptd Ltd v International Trade Corporation Ltd [2013] EWHC 111 (QB), [2013] 1 All ER (Comm) 1321 and commentaries derived therefrom such as $\mathrm{H}$ Collins, 'Implied Terms: The Foundation in Good Faith and Fair Dealing' (2014) 67 Current Legal Problems 297 and D Campbell, 'Good 
Viewing labour law history as a story of the collective and individual periods, the latter being the present, duress is a common touchstone for economic interests. In the collective era, duress (particularly economic duress) was a sort of rallying call against trade unions. Putting the concession in Universe Tankships aside, Lord Wedderburn gave a reminder that it was 'inevitable ${ }^{25}$ that economic duress would enter into the labour law discussion because coercion is at the heart of contracts of employment: 'The individual worker who accepts engagement rather than starve or who obeys an employer's orders rather than be dismissed into unemployment is not normally understood by lawyers to have suffered from "economic duress" (though his will was surely "overborne"). ${ }^{26}$ Coercion is contract negotiation if we are to follow the comments in a leading decision: 'Illegitimate pressure must be distinguished from the rough and tumble of the pressures of normal commercial bargaining. ${ }^{27}$

With the 1980s, England embraced the argument of duress in order to tame the influence of unions. Further into the twenty-first century, duress arguments persist. They have moved away from trade unions. ${ }^{28}$ The durability of the duress argument should be appreciated because, agree or disagree, it remains a remarkably influential premise, facilitating a change that sees workers (employment regulation of individual workers) replacing trade unions as the anchor of the economy.

\section{NOT YET}

Employment regulation has once again been viewed as a problem and economic duress has underpinned the argument for reform. Now, it is not the legal concept taken from contract law but the phrase in a non-legal sense. Individual workers present economic problems. First, workers may too easily launch an employment claim. Once claims are made employers incur costs. ${ }^{29}$ Surveys of employers are used to evidence the

Faith and the Ubiquity of the "Relational Contract"' (2014) 77 Modern Law Review 460. Professor Douglas Brodie - D Brodie, 'How Relational Is the Employment Contract?' (2011) 40 Industrial Law Journal 232 has doubted the viability of the intersection between relational contracts (per Macneil) and UK employment law. For some time Professor McKendrick has argued against adoption of relational contracts in the UK: E McKendrick, 'Long-Term Contracts in English Law' in J Beatson and D Friedmann (eds), Good Faith and Fault in English Law (Clarendon Press 1995) 305.

Lord Wedderburn, 'Economic Duress' (1982) 45 Modern Law Review 556, 560.

26 Ibid.

27 DSND Subsea Ltd v Petroleum Geo-Services ASA [2000] BLR 530, [131].

The wage premium (the difference in pay between unionised and non-unionised workers) has declined since 1995 to the point that the 'trade union wage premium for public sector workers was 10.5 percentage points lower in 2013 compared with 1995, while for the private sector, this was 8.3 percentage points lower over the same period': Trade Union Membership 2013 (n 6) 9.

29 E Jordan and others, 'Part A: Employer Perceptions and the Impact of Employment Regulation' Employment Relations Research Series 123 (BIS, March 2013) [Jordan and others], 18. These are not new assertions. For example, Lord Jones in the course of debates on the Employment Act 2008 identified abuses by workers: Hansard HL Deb 25 February 2008, vol 699, col GC74. 
assertions. Consider the following: $67 \%$ of employers believe employment regulation is a barrier to the UK's market competitiveness; $34 \%$ of claims are withdrawn by applicants; employers are four times more likely to win but $26 \%$ are still settling even when told they can win. ${ }^{30}$ Second, low productivity levels in the UK obstruct economic development. Private sector per hour labour productivity was at about $8 \%$ below its pre-crisis peak as of August $2013,{ }^{31}$ but it has risen by $1.7 \%$ more than expected since the recession. ${ }^{32}$ The measurement is based on comparison with the highpoint of 2007 Quarter 4 figures. ${ }^{33}$ And yet, labour law has been an area in which belief has often trumped evidence. ${ }^{34}$ Preceding the recession of 2008/09, the 2007 Q4 comparator must be challenged as it represented a peak in a questioned framework. ${ }^{35}$ The danger in looking at the predicament as one of low labour productivity is that it easily falls into a theme that in England has a long history - worker lethargy and its associated ills. The outlook ignores that both productivity and wages over the last 40 years have increased and Office for National Statistics (ONS) data from July 2014 shows that productivity has surpassed real wages (keeping in mind a figure of $87 \%$ inflation during that period). ${ }^{36}$ This fall has been pointed to as an explanation for why UK employment was not more greatly affected during the recession. ${ }^{37}$ It also overlooks how workers during The Great Recession, according to the Governor of the Bank of England, seemed to have 'effectively priced themselves into low-productivity work at a time of weak demand'. ${ }^{38}$ This is not to cast aside positives. For example, lower wages may have contributed to keeping employment levels higher during trying economic times. As well, maintaining some level of employment helps workers retain and develop new skills. ${ }^{39}$ Still, the lower productivity figure precipitated concerns which the government believed must be solved through these measures.

Confederation of British Industry, Facing the Future: CBI/Harvey Nash Employment Trends Survey 2012 (London: CBI, 2012) 25-26. This publication is used as an example of supporting surveys.

Bank of England, Inflation Report August 2013 (London: Bank of England, 2013) [Inflation Report August 2013], 26.

Bank of England, Inflation Report November 2014 (London: Bank of England, 2014), 33.

N Oulton and M Sebastia-Barriel, 'Long and Short-Term Effects of the Financial Crisis on Labour Productivity, Capital and Output' (2013) Bank of England Working Paper No 470.

For an elaboration of this critique, see S Slinn, 'The Limitations of Pieces of Paper: A Role for Social Science in Labour Law' (2006) 12 Canadian Labour and Employment Law Journal 291.

The Bank of England questioned the sustainability of the financial services sector's productivity prior to the recession: Inflation Report August 2013 (n 31).

6 ONS, 'UK Wages Over the Past Four Decades - 2014'. B van Wanrooy and others, The 2011 Workplace Employment Relations Study: First Findings (London: BIS, 2013) [WERS 2011, First Findings] have also noted a fall in real terms of average earnings. The recession, however, does not explain away a troubling trend.

7 Brigid van Wanrooy et al, Employment Relations in the Shadow of Recession (Basingstoke: Palgrave Macmillan, 2013) [WERS 2011 Final], 121.

38 Bank of England, 'Remarks given by Mark Carney, Governor of the Bank of England' Davos CBI British Business Leaders Lunch (24 January 2014), 7.

Ibid, 8 . 
Given the aforementioned situation, are there prospects for labour law to fulfil a promise of improvements for workers? Recent circumstances suggest new obstacles in the way of such realisation. The genesis of these new challenges is a focus on small to medium-sized enterprises (SMEs) as the motivation for employment regulation. (SMEs are employing enterprises with between 1 and 249 workers. ${ }^{40}$ In the UK, BIS business plans contained priorities which engaged with SMEs. In particular, the following priorities are especially resonant: Markets - where part of the plan has been to create a positive business environment by implementing reforms to the BIS employment laws framework, working with other Departments to support a fair, effective and efficient labour market'. ${ }^{41}$

The UK shares this focus on SMEs with the European Commission (EC). The EC has emphasised the importance of work to support SMEs with the aim of creating growth champions within the jurisdiction. ${ }^{42}$ In 2008, the Small Business Act was introduced to foster entrepreneurship for SMEs who were poised to take advantage of globalisation. There was a sense of frustrated urgency at that time: for example one of the headings was entitled 'Time for a Breakthrough'. 'Red tape' anchored SMEs' progression into stronger, larger businesses. Entrepreneurs were also a group of concern in 'Think Small First'. It seems as though continuing efforts to support the SME cohort have been identified. More recently, the Commission has devised COSME, ${ }^{43}$ 'the EU programme for the Competitiveness of Enterprises and Small and Medium-sized Enterprises (SMEs) running from 2014 to 2020 with a planned budget of $€ 2.3 \mathrm{bn}$ '. ${ }^{44}$ COSME is overseen by the Executive Agency for Small and Medium-Sized Enterprises (EASME). ${ }^{45}$

SMEs consist of three sub-groups: micros (1-9 employees); small (10-49 employees); and medium (50249 employees). This is the breakdown used by the European Commission following EU Recommendation 2003/361, OJ L 124/38, 20.5.2003, 'Concerning the definition of micro, small and medium-sized enterprises'.

41 This 'Market' priority is drawn from the BIS Business Plan 2012-2015 (2012). Other priorities are also relevant (for example Skills - Build an internationally competitive skills base and promote more opportunities for individuals in realising their potential; Enterprise - Boost enterprise and make this the decade of the entrepreneur. Under this action, BIS has been planning to 'recruit and train 15,000 mentors (5000 funded by the Government Equalities Office) to provide additional mentoring capacity for SMEs.').

42 See for example European Commission, 'Communication from the Commission to the Council, The European Parliament, The European Economic and Social Committee and the Committee of the Regions' COM (2008) 394 final (25 June 2008), 2, where it was written: 'capacity to build on the growth and innovation potential of small and medium-sized enterprises (SMEs) will therefore be decisive for the future prosperity of the EU'.

43 Established by EU Regulation 1287/2013 (11 December 2013).

44 Art 5 of EU Regulation 1287/2013 contains an outline of how the budget is to be spent.

45 http://ec.europa.eu/easme/index_en.htm accessed 9 January 2015. Of the four categories of objectives in COSME, employment regulation efforts seem to fit best under the third, improving framework conditions for the competitiveness and sustainability of Union enterprises, particularly SMEs, including in the tourism sector'; though the fourth objective also has application ('promoting entrepreneurship and entrepreneurial culture'). EU Commission, 'ANNEX to the Commission Implementing Decision concerning the adoption of the work programme for 2014 and the financing for the implementation of Programme for the Competitiveness of Enterprises and small and medium-sized enterprises' C(2014) 247 final. These are also found in Art 4(1)(c), (d) of EU Regulation 1287/2013. 


\section{A. Employment Tribunal Reforms: Not Yet Becomes if Ever?}

Against the backdrop of fostering small to medium-sized enterprises, the changes to English employment tribunal procedure have been premised on the notion that workers launch scores of frivolous employment claims. These actions create business expenses, thereby draining the English economy. It must be a remarkable time when overhaul of employment tribunal procedure is viewed as a way to improve a country's economy. Underlining the role of labour law as a support to economic growth, an overarching aim of the Coalition Government's Employment Law Review was 'to address the reality that businesses see that the cost and complexity of employment laws impact on their ability to take on staff and grow'. ${ }^{46}$

The Coalition picked up the mantle from the John Major Conservative Government through the changes brought in by the Enterprise and Regulatory Reform Act 2013, Part $2^{47}$ as well as the Employment Tribunals (Constitution and Rules of Procedure) Regulations 2013. ${ }^{48}$ The Green Paper of the Major Conservative Government Resolving Employment Rights Disputes: Options for Reform expressed concern over industrial tribunals offering 'a readily accessible and cost effective means of redress' ${ }^{49}$ The 2013 package may assist employers, but more remarkable was the government's ambivalence regarding employment protections. These reforms put into question access to redress for potential infringements of employment rights and, most significantly, tilted the balance more clearly towards economic stimulation rather than rights protection. In effect, the package of reforms instituted a plan of organic dissuasion of redress as an economic strategy.

\section{(a) Financialising tribunal claims}

The centrepiece of the reforms was costs. ${ }^{50}$ The Employment Tribunals and the Employment Appeal Tribunal Fees Order $2013^{51}$ introduced fees for bringing an employment claim for the first time since the industrial tribunals were established by the Industrial Training Act 1964. These monies had already been allocated to offset some of the planned 23\% budget reduction over four years (beginning in 2011). ${ }^{52}$ The government expected to recover approximately $33 \%$ of the cost of employment tribunal proceedings

BIS, 'Employment Law Review Annual Update 2012' (London: BIS, March 2012), 6. The government claimed that these changes would save businesses $£ 40$ million per year.

2013 Chapter 24. Royal Assent 25 April 2013 [ERRA].

SI 2013/1237 (in force as of July 2013) [2013 Regulations].

Employment Department, Resolving Employment Rights Disputes: Options for Reform (Cm 2707, 1994), [1.2].

My gratitude to David Renton of Garden Court Chambers for his observations regarding this part. SI 2013/1893 (in force 29 July 2013). For details of the fee scheme, see D Pyper and F McGuiness, 'Employment Tribunal Fees' (2015) House of Commons Library SN 07081, 5-8.

BIS, Resolving Workplace Disputes: A Consultation (London: BIS, 2011) [Resolving Workplace Disputes] 49. 
through these fees. ${ }^{53}$ Figures for 2013-14 show that the government spent $\mathfrak{E} 76.4$ million on employment tribunal business and recouped $\mathfrak{E} 4.5$ million (net) in fees (6\% of expenditure). ${ }^{54}$ These fees underscore how employment regulation has been imbued with an economic imperative.

The most difficult measurement is also the most important: the impact on employment adjudication. Two circumstances have been foreseeable: a decrease in the number of claims and a rise in the number of self-represented claimants. At its core, the notion that fees will result in a decrease in claims asks the question: does employment regulation impact on practice in the area? The answer is, it does. The Unfair Dismissal and Statement of Reasons for Dismissal (Variation of Qualifying Period) Order 2012, ${ }^{55}$ which doubled the qualification period for unfair dismissal from one to two years, ${ }^{56}$ confirms the impact of employment regulation. Unfair dismissal claims fell from $50 \%$ in 2008 down to $33 \%$ of total claims in 2013. Payment of Tribunal Awards, ${ }^{57}$ from which this data was obtained, looked at claims between September 2011 and November 2012. The Order came into effect on 6 April 2012 which may have resulted in an increase in the number of claims just prior to this date (an occurrence witnessed just before the 29 July 2013 coming into force date of the Employment Tribunals and the Employment Appeal Tribunal Fees Order 2013). ${ }^{58}$ The noted decrease in unfair dismissal claims is suggestive of a similar drop in the overall number of claims with respect to the influence of the Tribunal Fees Order. A drop was predicted as a result of the introduction of fees. ${ }^{59}$ Early data suggested there has been a significant decrease. Mr Justice Langstaff identified a decrease in applications of one-third in his 2014 report. ${ }^{60}$ Data from September 2014 denoted a drop of 70\% in single claims and multiple claims fell from 1500 in April-June 2013 to 500 in the same period in $2014 .{ }^{61}$ Receipts of claims at the employment tribunal fell from an average of 48,000 new claims per quarter to 8540 new claims in the period April to June 2014. ${ }^{62}$ These figures have arisen despite the possibility of

See Employment Tribunal and Employment Appeal Tribunal Fees Stakeholder factsheet http://www. justice.gov.uk/downloads/tribunals/employment/et-fees-factsheet.pdf accessed 9 January 2015. Recall many workers found completing the preceding version of ET1 forms for claims to be a 'daunting experience': N Busby and M McDermont, 'Workers, Marginalised Voices and the Employment Tribunal System: Some Preliminary Findings' (2012) 41 Industrial Law Journal 166, 175. Pyper and McGuiness (n 51) 13.

55 SI 2012/989.

56 Ewing and Hendy have questioned the reason for the increase in the qualification period: K Ewing and J Hendy 'Unfair Dismissal Law Changes - Unfair?' (2012) 41 Industrial Law Journal 115, 116.

57 IFF Research, Payment of Tribunal Awards (London: BIS, 2013) [Payment of Tribunal Awards].

58 SI 2013/1893.

59 Underhill J recorded opposition to the introduction of fees, calling it a 'powerful disincentive' to bringing a claim: Fundamental Review of Employment Tribunal Rules (London: Royal Courts of Justice, 2012), [10]. Senior President of Tribunals' Annual Report 2014 (London: Royal Courts of Justice, 2014) [Senior President Report], 63.

61 Ministry of Justice, 'Tribunal Statistics Quarterly April-June 2014', 8.

62 Ibid, 25. Published figures differ depending on the period assessed and the breakdown of the numbers (for example single versus multiple claims). Her Majesty's Courts \& Tribunal Service (HMCTS), 'Employment Tribunal Fees for Individuals' T435 (London: HMCTS, 2013), 9, is one example. 
reimbursement being ordered by tribunals for successful claimants. ${ }^{63}$ To be generous, it may be said that the introduction of the fees scheme has had a deterrent effect. ${ }^{64}$ The consequence of fewer cases poses some troubling potential for the growth of case law in the area. The last monumental development at common law was the mutual obligation of trust and confidence. It will remain in question whether fees reduce the probability of developments in the discipline.

Tribunal fees have been challenged by Unison but as yet the union has not been successful. At a first hearing, ${ }^{65}$ the court found the matter to be premature. ${ }^{66}$ The government's submission included the following argument:

The Court was treated to lengthy citation on behalf of the Lord Chancellor of a Hansard report of debate when the Order was introduced, in which the Minister disavowed any intention to deter individuals from bringing a claim. She emphasised the need to reduce what she described as 'an inordinate number of claims' which are 'longwinded, expensive, protracted and emotionally draining disputes ... certainly not in the interests of individuals or of business'. ${ }^{67}$

This statement would appear to be an example of indirect effect where the government contended its direct intention was to address the number of claims, but change also deterred individuals from initiating claims. Later in 2014, the matter again reached the Administrative Court as Unison argued it now had the evidence (largely focusing on the costs as they affect impoverished claimants ${ }^{68}$ within the EU framework) the court found wanting in the earlier decision. ${ }^{69}$ Again the claim failed based on the absence of specific facts ${ }^{70}$ and evidence suggesting there was a burden on, as opposed to a choice for, claimants to make. ${ }^{71}$ Professor Novitz has queried what evidence

HMCTS stated at the time tribunal fees came into effect - 'The general position is that, if you are successful, the respondent will be ordered to reimburse you': HMCTS, 'Employment Tribunal Fees for Individuals' T435 (2013), 7. Further guidance on reimbursement has been provided by the EAT: Portnykh $v$ Nomura International plc (UKEAT/0448/13/LA); Horizon Security Services Ltd v Ndeze [2014] IRLR 854; and Look Ahead Housing and Care Ld $v$ Chetty (UKEAT/0037/14).

64 Along the more neutral lines of statement, see Elias LJ in $R$ (on the application of Unison) $v$ The Lord Chancellor [2014] EWHC 4198 (Admin), [2015] ICR 390 [Unison (No 2)], [60], where he wrote: 'The figures demonstrate incontrovertibly that the fees have had a marked effect on the willingness of workers to bring a claim but they do not prove that any of them are unable, as opposed to unwilling, to do so.' Unison v Lord Chancellor [2014] EWHC 218 (Admin), [2014] IRLR 266 [Unison No 1].

66 'The mere fact that fees impose a burden on families with limited means and that they may have to use hard-earned savings is not enough. But it is not possible to identify any test for judging when a fee regime is excessive. It will be easier to judge actual examples of those who assert they have been or will be deterred by the level of fees imposed': ibid, [42].

67 Ibid, [44].

68 The scheme in place for those who cannot afford to pay these fees is set out in the Courts and Tribunal Fee Remissions Order 2013 (SI 2013/2302) as amended by the Courts and Tribunals Fees (Miscellaneous Amendments) Order 2014 (SI 2014/590). For an explanation of this scheme, see Pyper and McGuiness (n 51) 8.

69 [2014] EWHC 4198 (Admin) [Unison No 2], [4].

70 Ibid, [62], [98].

71 Ibid, [61]. 
would be satisfactory to establish that fees have deterred litigants. The paradox of these cases is that if litigants come to the court as a result of this type of challenge they have the support of a trade union. There is much to be said about the interpretation of choice in this context.

Observers of English labour law will note the increasing reference to relevant Canadian case law in English academic commentaries and again there is occasion here. The Supreme Court of Canada dealt with the issue of trial hearing fees in Trial Lawyers Association of British Columbia v British Columbia (Attorney General). ${ }^{72}$ The facts, briefly, were that the claimant was a qualified veterinary surgeon (not working at the time) from Europe who was involved in a custody dispute. The Province of British Columbia started hearing fees with the aim of establishing a revenue neutral trial service. ${ }^{73}$ For the claimant's case, the hearing fee was about $\$ 3600$ to be paid in advance of the hearing (neither party was represented by a lawyer). This figure was equivalent to the net family income. Legal fees leading up to the hearing left savings depleted. The claimant did not qualify for fee remission (fee waiver). The Supreme Court ruled that the claimant was exempt from the fee and found the fee scheme unconstitutional. It was left to the Legislature to address points raised in the decision. In comparison to the English decisions, the comments from the Canadian Supreme Court recall Unison's position: 'If people cannot bring legitimate issues to court, the creation and maintenance of positive laws will be hampered, as laws will not be given effect. ${ }^{74}$ The idea of exemptions for the impoverished had been a focal point to the challenge in England. The Canadian Supreme Court delved further into the matter: ' ... providing exemptions to the truly impoverished may set the access bar too high. A fee that is so high that it requires litigants who are not impoverished to sacrifice reasonable expenses in order to bring a claim may, absent adequate exemptions, be unconstitutional because it subjects litigants to undue hardship, thereby effectively depriving access to the courts. ${ }^{75}$ This is not a matter considered by the court in either of the Unison challenges and yet perceiving of tribunal fees as only being about the 'poor' misses the breadth of this profound issue.

The Coalition's employment regulation reforms also pose a profound challenge to the practice of worker-side employment law. As alluded to above, there is likely to be less work for this cohort of solicitors and barristers because of the financial disincentive. Moreover, a further consequence of fees is that those who wish to pursue claims may well do so on their own, depending on the case. For example, data from Payment of Tribunal Awards ${ }^{76}$ reveals $67 \%$ of claimants were likely to seek assistance for an unfair

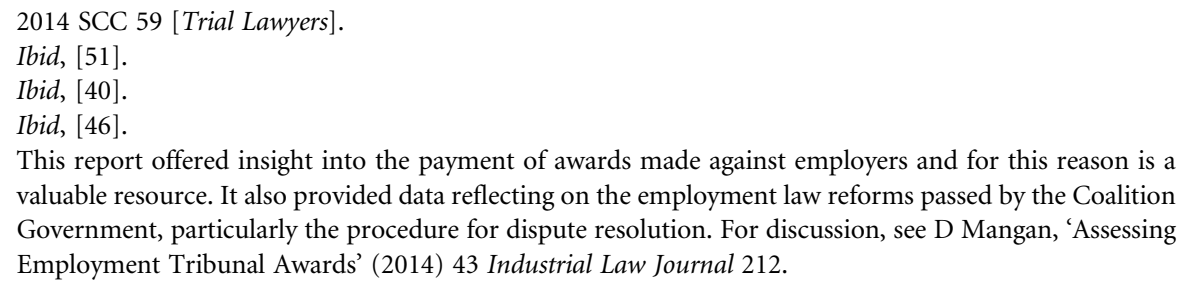


dismissal claim and 57\% sought assistance from solicitors. ${ }^{77}$ And yet for wage claims, claimants were more likely to access free advice through the Citizens Advice Bureau (30\%) or Acas (12\%). ${ }^{78}$ Overall, only $42 \%$ of claimants had sought advice from legal professionals. Twenty-five per cent of claimants sought advice from the Citizens' Advice Bureau, while 19\% used family and friends' assistance. The prospect for self-representation is readily apparent to those working in employment law. ${ }^{79}$ Self-representation means greater demands on resources dependent on government funding which as yet do not seem to be increasing in concert with any foreseeable increase in use. More profoundly, tribunals will be placed in the unenviable position of weighing the fact of self-representation and ensuring fairness for those individuals during proceedings. ${ }^{80}$ Sadly, circumstances appear to have changed little if practice evolves in this manner. The reforms are premised on cost certainty for employers so that the overall numbers are reduced thereby presenting a cost saving through employment regulation.

As is the case with labour law, there is always a sliver of positive. A recent report on the workplace defined contribution pension scheme offered some intriguing points. Though early in its development, this pension scheme ties into the present discussion insofar as it presents some arguments contrary to recent labour law trends. In the Regulatory Policy Committee's Impact Assessment, ${ }^{81}$ the problem at which the scheme was aimed was couched within the Office of Fair Trading's defined contribution (DC) market study ${ }^{82}$ which 'found that competition alone cannot be relied upon to drive value for money in the DC workplace pension market due to weaknesses in the buyer side of the market and the complexity of the product. Government intervention is necessary to ensure all individuals saving into a workplace pension get value for money. ${ }^{83}$ The laissez-faire ethos is put aside here. Even competition is discounted: government intervention is needed because 'competition alone' will not achieve the desired results. Workplace pensions carry forward one trend of the twenty-first century, downloading responsibility. Pensions are so important, however, the government is willing to add cost (often called a

\section{dent Report (n 60) 64.}

Those who have been in a hearing when a self-represented party presents his/her case can attest to the great efforts undertaken by those presiding to compensate for the party's lack of legal background. Perhaps this explains in part the $50 \%$ decrease in the disposal of employment tribunal claims over the period April-June 2014: Ministry of Justice, 'Tribunal Statistics Quarterly AprilJune 2014', 11.

81 Michael Gibbons (Chairperson), 17 March 2014, RPC14-DWP-2032 [DC Workplace Pensions Impact Assessment].

82 Office of Fair Trading, Defined Contribution Workplace Pension Market Study (OFT 1505, 2013).

83 DC Workplace Pensions Impact Assessment (n 81) [no pagination]. 
burden in the labour context) to private sector employers. ${ }^{84}$ This is a noteworthy development as there is a connection being drawn between government (reductions in) spending and protection of defined contribution pension remuneration packages for private sector workers.

\section{(b) Coercion as dispute resolution}

If claims are initiated, then they are to be dealt with swiftly. If the claimant brings forward a claim, the required forms now state median awards. ${ }^{85}$ These figures are lower and more representative ( $(4560)$ than the average awards ( $(9133)$, themselves buoyed by a few larger sums. ${ }^{86}$ Figures from the first few months of early conciliation show 17,145 notifications (of which 540 were by an employer and the remainder by a worker).

With the changes, the expectation is that many cases be disposed of through the early conciliation process. ${ }^{87}$ At the outset and before a hearing, workers ('prospective claimants') must report their claims details to Acas. ${ }^{88}$ The prospective claimant is to complete a form (online or sent by post) or must call Acas. ${ }^{89}$ The timeline is up to 'one calendar month starting on the date of receipt of the form (or call to Acas)'. ${ }^{90}$ During the prescribed period, a conciliation officer 'shall ... endeavour to promote a settlement between the persons who would be parties to the proceedings'. This is achieved by Acas making attempts to contact the prospective claimant and, if consent is given, the prospective respondent. ${ }^{91}$ If contact is not made, Acas 'must conclude that settlement is not possible..$^{92}$ If settlement is not possible or the period expires, the prospective claimant must obtain a certificate confirming the close of the prescribed period. ${ }^{93}$ Still, Acas conciliation is not mandatory (either party can refuse). ${ }^{94}$

Despite attempts to foster growth in private sector employment. See for example the Private Sector Employment Indicator, the aim of which is to 'monitor the underlying growth in private sector employment': BIS, 'Private Sector Employment Indicator, Quarter 4 2013' (Nov 2013 to Jan 2014) (2014).

BIS, Employment Law 2013: Progress on Reform (London: BIS, 2013) [Progress on Reform], 25.

Ministry of Justice, 'Employment Tribunals and EAT Statistics, 2011-12' (1 April 2011 to 31 March 2012) (London: Ministry of Justice, 2012).

The Enterprise and Regulatory Reform Act 2013 (Commencement No 5, Transitional Provisions and Savings) Order 2014 (SI 2014/253) (in force as of 6 April 2014).

Section 7 of the Enterprise and Regulatory Reform Act 2013 which adds s 18A to the Employment Tribunals Act 1996.

9 Employment Tribunals (Early Conciliation: Exemptions and Rules of Procedure) Regulations 2014 (SI 2014/254), Sch, rr 1, 2.

Ibid, Sch, r 6(1). An extension of 14 days may occur once upon consent from the prospective claimant and respondent: Sch, r 6(2), (3).

Ibid, Sch, $\mathrm{r} 5$.

Ibid, Sch, r 5(3).

Ibid, Sch, $\mathrm{r} 7(2)$.

BIS, Ending the Employment Relationship: Government Response to Consultation (London: BIS, 2013)

[Ending the Employment Relationship], [108]. 
Mandatory consultation finds its basis in the idea of costs. Since less than onethird of claimants sought out Acas, the government speculated this body could reduce the number of claims reaching the tribunal stage by $12,000 .^{95}$ Early figures from Acas show 7\% of workers and 9\% of employers (where the worker agreed) opted out of early conciliation. ${ }^{96}$ Acas updated these figures cumulatively and so data includes the period from April to September 2014, finding 10\% rejected conciliation. $^{97}$

Mandating Acas be involved delays expenditure by employers and also means the claims may potentially be averted. Data from Acas indicates some impact (though it is difficult to determine its significance at this point) on the early conciliation process. Of the 11,355 cases that ended their early conciliation period in the period April-June 2014, 1873 cases reached settlement (called COT3) which was $16.5 \%$ of the total. ${ }^{98}$ The only other data available found $19 \%$ of those who went through conciliation without settlement decided to abandon the claim; ${ }^{99}$ though there was no indication as to why this decision was taken. Acas' update on these figures was cumulative and did not separate findings from the previous release. ${ }^{100}$ And so, data covered the period April to September 2014, 17,162 cases in total. Of these 18\% reached COT3 (3046); 24\% proceeded to Tribunal (4198); and $58 \%$ (9918) did not proceed. For those who suggested that many frivolous claims are launched, the $58 \%$ of claims that do not proceed may be viewed as vindication. However, Acas remains unclear as to the reasons for abandonment. Here will be a lingering question: how many cases will move to the tribunal stage and for what reasons will cases be abandoned? Tracking all of this information will be quite important to an overall assessment of the effectiveness of early conciliation.

If the claim continues past conciliation, the second tier of dispute resolution is the settlement offer. The amendments to the established settlement offers stand out as a means of incentivising the early resolution of disputes. ${ }^{101}$ While it may be said the

95 Resolving Workplace Disputes (n 52) 21-22. WERS 2011, First Findings (n 36) suggested that many may continue to opt out of this process as the authors found few used dispute resolution: WERS 2011, First Findings (n 36) 27.

96 This data related to the period April to June 2014. Acas, 'Early Conciliation Update: Quarter 1 April-June 2014’ (2014) http://www.acas.org.uk/index.aspx?articleid=4960 [Acas Quarter 1 Update] accessed 9 January 2015.

97 For this period, Acas reported a total of 37,404 notifications (of which 36,162 were workers and 1242 were employers making contact with Acas). Acas reported 10\% rejected offers of conciliation - 3783 (workers) and 3727 (employers): Acas 'Early Conciliation Update: April - September 2014' (2014) http://www.acas. org.uk/index.aspx?articleid=5069[Acas 2014 Second Update] accessed 22 January 2015.

98 Acas Quarter 1 Update (n 96).

99 Ibid.

100 Acas 2014 Second Update (n 97).

101 'we propose to introduce a Rule whereby either party can make a formal settlement offer to the other party or parties as part of formal employment tribunal proceedings. This procedure would be backed by a scheme of penalties and rewards, in order to encourage the making - and acceptance - of reasonable settlement offers': Resolving Workplace Disputes (n 52) 37. 
government subscribed to Gibbons' suggestion of early resolution of disputes (notably at an informal stage), ${ }^{102}$ its perspective on early resolution would appear to focus on the benefits for one side. Section 111A of the Employment Rights Act 1996 is an example. While settlement negotiations remain inadmissible at tribunal, ${ }^{103}$ the Act now provides a way for 'improper behaviour' ${ }^{104}$ to be put before the tribunal:

(4) In relation to anything said or done which in the tribunal's opinion was improper, or was connected with improper behaviour, subsection (1) applies only to the extent that the tribunal considers just.

(5) Subsection (1) does not affect the admissibility, on any question as to costs or expenses, of evidence relating to an offer made on the basis that the right to refer to it on any such question is reserved.

The identified objectives behind a finding of impropriety are of importance because this behaviour is the benchmark for the admissibility of settlement negotiations: ${ }^{105}$

we envisage a scheme requiring or empowering an employment tribunal to increase or decrease the amount of any financial compensation which is ultimately awarded where parties have made an offer of settlement which has not reasonably been accepted. Wherever no award is made (i.e. the claim is lost), and a reasonable offer of settlement has been made to the claimant we envisage that such a fact could be used by a tribunal in considering whether the claimant had pursued the case 'vexatiously, abusively, disruptively or otherwise unreasonably', or in a way that was 'misconceived'. ${ }^{106}$

Concerns about improper behaviour and the vexatious suggest that the aim is more about dispensing with claims. If an offer is not accepted and the claim is lost, the government has enacted a measure that may punish a losing party. ${ }^{107}$ The focus on boosting the economy places the emphasis with regard to settlement offers on the disposal of claims.

To call these changes a commitment to alternative dispute resolution (ADR) would be a disservice to ADR. Instead, this system of dispute resolution is more in the line of coerced conflict resolution. From the forms claimants are to fill out (which inform of

102 M Gibbons, Better Dispute Resolution: A Review of Employment Dispute Resolution in Great Britain (DTI 2007), Chapter 2.

103 Section 111A(1), (2) of the Employment Rights Act 1996, as amended. This was anticipated in an earlier government report - 'we are amending the Employment Rights Act 1996 to provide that an offer of settlement is inadmissible as evidence to an employment tribunal in any subsequent unfair dismissal claim effectively extending the existing "without prejudice" regime to situations where no formal dispute has yet arisen': Ending the Employment Relationship (n 94) [24].

104 A similar point can be made about s 15 of the ERRA (amending s 124 of the Employment Rights Act 1996) which permits the employment tribunal to increase or decrease a compensatory award based on improper conduct.

105 Government seeks to protect both parties from 'improper behaviour' and if this is found the rule regarding the inadmissibility of settlement agreements will not apply: Ending the Employment Relationship (n 94) [37].

106 Resolving Workplace Disputes (n 52) 37.

107 The power to award costs against parties pursuant to rr 75 and 76 in the 2013 Regulations is a further consideration to bringing an employment claim. 
median awards figures) to claimants' obligation to report claims to Acas first, procedure is tailored to put the emphasis on claimants and keep it there. Employment claims (moving forward) will be a war of attrition which workers are not well equipped to survive. There are built-in steps that (using the gambling analogy common amongst critics of employment protections) make employment actions a poor bet despite the hand one may have.

\section{B. The Unproductive Weakening of Labour Employment Law}

The Coalition Government reforms have weakened labour law and arguably challenged innovation/growth. These developments stifle productive innovation when it comes to managing personnel because so much has been done to eliminate concerns about workforce management: problems are fixed by relaxed employment regulation and so decisions about the workforce garner less than a productive amount of attention. To be clear, this argument is not a generalisation of English enterprise. Instead, as happens too often with blunt one-size-fits-all reforms, those who are engaged in good practices which usefully maximise human resources are insufficiently recognised because attention is diverted to those less than stellar examples. The argument here is that the foundations of the reforms are more of a quicksand than solid ground.

As a motivation, facilitating growth for small to medium-sized businesses is an understandable strategy. According to 2013 statistics from BIS, small to mediumsized firms accounted for a combined $59.3 \%$ of UK private sector employment and they constituted about $99.9 \%$ of private sector businesses. ${ }^{108}$ Between 2000 and 2013 SMEs have grown rapidly, increasing in number by about $41 \%$ during that period. ${ }^{109}$ Given this figure, it is comprehensible why the government's current plan for employment regulation focuses more squarely on this group. Sixty-eight per cent of claims were made against this cohort: $33 \%$ of claimants filed cases against employers with 1 to 9 employees; 35\% against employers employing between 10 and 49 workers; $11 \%$ against undertakings with 50 to 249 workers. ${ }^{110}$ And yet, there is reason to raise questions. In the SME Business Barometer February 2014, ${ }^{111}$ SME employers were asked (based on a list read to them) which represented an obstacle to the success of their businesses. Sixty-two per cent identified the economy (which was $10 \%$ less than the June 2013 figure); 49\% cited taxation; 21\% identified staff recruitment (though what this term refers to is unclear) and this was up from $16 \%$ in June 2013. By using SMEs as a target group, the aims of employment regulation have shifted to that of an easy-to-use format where ease in engaging workers (with

108 BIS, Business Population Estimates for the UK and Regions 2013 (London: BIS, 2013) [Business Population 2013].

109 Ibid, 5.

110 Payment of Tribunal Awards (n 57) 20.

111 SME Business Barometer February 2014 (London: BIS, 2014) [SME Business Barometer February 2014 ], 32. 
minimal regulatory considerations) is facilitated. The reform package charts a retrenchment of the parameters for access to redress which has the potential to limit the enforcement of recognised employment rights, especially when determined by their impact on business.

Several considerations suggest that this cohort forms a dubious premise for such significant regulation. First, SMEs prefer to have an informal workplace; ${ }^{112}$ that is, few if any formal written policies. ${ }^{113}$ Gibbons wrote that small businesses preferred the informal workplace because expressing 'problems in writing can act as a trigger for greater conflict'. 114

Consequently, and second, this choice exposes them to greater potential liability at employment tribunals for the absence of formal procedures. A large number of workers in businesses of between five and nine were highly likely to have a positive view of the workplace. ${ }^{115}$ Despite this, empirical evidence underlined the accompanying risk: 'Wider research has shown that small employers are more likely to be involved in, and lose, employment tribunals, particularly those that did not follow formal processes when dealing with disputes'. ${ }^{116}$ The reason for loss at the employment tribunal was not singularly attributable to the absence of human resources support ${ }^{117}$ because the application of procedures 'makes the difference between winning or losing a case'. 118

Third, while SMEs are the fastest growing entity in the private sector, much of that growth is the result of increases in the number of businesses with no employees. ${ }^{119}$ BIS speculated that 'tough labour market conditions ... may have encouraged people to set up in business as they are made redundant. ${ }^{, 120}$ ONS data suggested $15 \%$ of the total workforce were self-employed in 2014. ${ }^{121}$ Based on BIS' Business Population 2013, the number of businesses that employ individuals currently sits at 100,000 more in 2013 than in 2000. This is quite a modest increase. There has been a movement from large entities (250 plus workers) to smaller, sole proprietor enterprises: at the start of 2013, $28.5 \%$ of private sector businesses were companies while $62.6 \%$ were sole

112 It is interesting to note the difference in attitude. An Acas case study on Blue Earth Foods conveys one example. Starting up in 2009 with 15 employees, Blue Earth grew fairly rapidly and in 2012 had over 300 workers (240 permanent and 80 agency). This growth prompted the hiring of the company's first HR manager the same year who summed up the challenge posed by the rapid growth: 'We've got to turn that nice, friendly, company into an organization that makes money'.

113 Employers who do not have procedures were identified as smaller sized operations in the Workplace Employment Relations Study: WERS 2011, First Findings (n 36) 27.

114 Gibbons (n 102) 2.11.

115 This figure was found to be 82\%: WERS 2011 Final (n 37) 164.

116 Jordan and others (n 29) citing G Saridakis and others, 'The Impact of Enterprise Size on Employment Tribunal Incidence and Outcomes: Evidence from Britain' (2008) 46 British Journal of Industrial Relations 469 [Saridakis and others].

117 Saridakis and others (n 117), 492.

118 Ibid, 493.

119 Business Population 2013 (n 109) 5-6.

120 Ibid.

121 ONS, 'Self-Employed Workers in the UK - 2014' (2014), 1. 
proprietorships (of which only 9\% employ anyone). (There was a small increase $(2.2 \%)$ in large businesses between 2012 and 2013.) Employment since 2008 has 'predominantly' increased as a result of self-employment. ${ }^{122}$ For example, between the first quarter 2008 and the second quarter 2014, employment rose by 1.1 million, but of that 732,000 were self-employed. ${ }^{123}$ There is a curious duality evident. Regulation is being undertaken in favour of the cohort. However, translation into increased employment is not arising: 22\% of SMEs employed fewer people by February 2014 than they did by February 2013. Only 18\% employed more workers. Surveys in February and June 2013 (immediately after extending the qualifying period for unfair dismissal protection from one to two years) show that $19 \%$ and $12 \%$ (respectively) hired more workers than in the previous 12-month period. In the same period, $21 \%$ and $28 \%$ (respectively) had fewer workers. It may be reasonable to assume SMEs need to feel secure before they hire. And yet, indications are that SMEs have a positive mindset: $74 \%$ made a profit in the previous 12 -month period; $85 \%$ expect to make a profit in the next 12 -month period; $66 \%$ aim to grow their business in the next two to three years. Overall there was a rise $(13 \%)$ in the number of respondents who increased their profit from one year prior and 36\% of SMEs improved their turnover (the largest 12-month increase in the Barometer's history dating back to 2008). In the next 12-month period, only $23 \%$ indicated they would employ more people versus $68 \%$ who would remain at status quo. In fact, the 'proportion of SME employers employing fewer has been higher than those employing more in every Barometer'. ${ }^{124}$

Fourth, another difficulty with regulating to the benefit of the SME cohort is they are most likely to be unaware of the assistance being provided to them. ${ }^{125}$ The report of Jordan and others identified this curiosity: 'There was no evidence that these employers were aware of the increased qualifying period for unfair dismissal'. ${ }^{126}$ SMEs' anxiety has driven these changes and yet that anxiety will remain. ${ }^{127}$ The difficulty here lies not in regulation but in informing a reluctant group. SMEs' inflated sense of risk in the absence of accurate information (and one could add reinforcing such an attitude by legislation) sets a dubious foundation for the success of reform efforts: since 'these employers felt they were at risk of litigation there was little motivation to change their working practices because they believed that working informally

122 Ibid, 3.

$123 \mathrm{Ibid}, 4$. The ONS report speculated that factors such as working past pension age and the absence of employment opportunities contributed to the higher number of individuals remaining in selfemployment.

124 SME Business Barometer February 2014 (n 112) 8.

125 Ignorance of the law or other information is not unique to the SME cohort, but it is a focus here as the findings challenge the merits of legislating in favour of this uninformed group. American studies, for example, have found workers to be unaware of their own employment protections: C Sunstein, 'Human Behavior and the Law of Work' (2001) 87 Virginia Law Review 205; P Kim, 'Bargaining with Imperfect Information: A Study of Worker Perceptions of Legal Protection in an At-Will World' (1997-98) 83 Cornell Law Review 105.

126 Jordan and others (n 29) 29.

127 See ibid, i. 
maintained better working relationships with staff and ensured managerial autonomy'. ${ }^{128}$ The adage regarding to where good intentions lead comes to mind.

SMEs seek free, bespoke materials readily accessible at any point in time and the Coalition vindicated this desire with its reforms. There is cause for pessimism that these changes will have the desired effect. ${ }^{129}$ Only 9\% of SMEs sought advice from lawyers. Younger businesses (0-3 years of existence) were more likely to seek out advice or information (64\%). Micros (1-9 employees) were most likely to not know where to go for advice or information. Most of those seeking advice or information desired financial advice on the running of the business $(23 \%)$ or business plans or strategy $(22 \%)$. Only $8 \%$ identified employment law/redundancy as a reason for seeking external assistance. As opposed to purchasing advice, SMEs are increasingly relying on mentors, ${ }^{130}$ underlining the no-cost version of advice.

Cost-sharing seems to be the government's next step. What SMEs may not know is that this plan involves them. Regional Mediation Pilot schemes in Cambridge and Manchester trained a group of employees from 24 SMEs to be mediators in order to help to resolve workplace disputes in the future. ${ }^{131}$ SMEs have been asked to band together to solve workplace issues. Creating a pool of mediators who will service an area appears to be the goal. When will these mediations occur? Will these employees be asked to mediate outside work hours? Will they be paid for conducting mediations? It is unclear what incentive there would be for the besieged SME cohort to take employee time away from their businesses.

The ease with which enterprises may retain and remove workers (in addition to the issue of redress) undervalues the importance of people being in paid work. The Bank of England has utilised the unemployment rate as a guide for informing its own economic policy: ${ }^{132} 7 \%$ unemployment had been the target set in 2013 by the Bank before it would raise the Bank rate from $0.5 \% .{ }^{133}$ Since that time, unemployment has been on a downward trend: $7.7 \%$ in September 2013, ${ }^{134} 6.5 \%$ in May 2014, ${ }^{135} 6.2 \%$ in May-July 2014 (the lowest since late 2008) (136 $^{136}$ and $6 \%$ as of October $2014 .^{137}$ While unemployment

SME Business Barometer February 2014 (n 112) 64

131 BIS, 'Regional Mediation Pilot Schemes up and Running' (2012) https://www.gov.uk/government/news/ regional-mediation-pilot-schemes-up-and-running accessed 9 January 2015.

132 Bank of England, Minutes of the Monetary Policy Committee Meeting 3 and 4 September 2013 [Minutes 2013].

133 Minutes 2013 (n 133), [20].

134 ONS, 'More People in Employment Compared with the Previous Quarter and the Previous Year' (11 September 2013) http://www.ons.gov.uk/ons/rel//ms/labour-market-statistics/september-2013/sty-employment.html accessed 9 January 2015.

135 Office for National Statistics (ONS), UK Labour Market, July 2014 (Newport: ONS, 2014). The Bank of England placed the Labour Force Survey unemployment rate at 6.4\% as of September 2014: Bank of England, Minutes of the Monetary Policy Committee Meeting 3-4 September 2014 [Minutes 2014], [23].

136 ONS, UK Labour Market, September 2014 (Newport: ONS, 2014).

137 ONS, Labour Market Statistics, October 2014 (Newport: ONS, 2014). 
figures show an increase in the number of people finding work, an important fact should be identified. A comparison of ONS data between May-July 2008 and the same period in 2013 shows that 328,000 more people were employed in 2013 than $2008 .{ }^{138}$ Much of the increase can be attributed to part-time employment being more available than full-time work: a jump from 689,000 individuals in part-time employment in this period in 2008 to 1.45 million in 2013 . The $7 \%$ unemployment figure that was identified as a threshold in 2013 has been a difficult one to pin down. For example, it does not factor in the type of employment. All forms of employment effect a decrease in unemployment. The type of work, however, should matter because regulation which facilitates the 'plugging in' of workers when needed and 'unplugging' them when not falls short of meeting anything more than a superficial target prone to perpetual fluctuation. A constant flow of new entry workers to unemployment after short periods of work leaves unemployment figures in constant peril, if a certain threshold of unemployment is viewed as a minimum for Bank action. At its essence, this form of employment regulation views English workers simply as a workforce to be accessed when needed. It leaves people in a continual search for secure work. The Bank of England noted that labour costs 'per unit of output were currently rising by only around 1\% per year, considerably weaker than was consistent with the inflation target in the long run'. ${ }^{139}$ Vulnerability persists when it comes to the ability of workers to face shocks to income and interest rates. ${ }^{140}$ Wages have fallen about a tenth since the economic crisis began (a fall not seen in the country since the 1920s). ${ }^{141}$ Government policy facilitating the easy increase of unemployment numbers may not be one supporting sustainable economic recovery. Overall, as a way of putting people to work, the procedural reforms remain curious because they facilitate greater ease in dismissing workers and deterring associated claims against employers.

\section{(a) Authoring the definitive narrative}

The Coalition package of labour law reforms betrays an unproductive attitude. ${ }^{142} \mathrm{Com}$ menting on the 2008 amendments of the Labour Government, Sanders characterised them as 'the start of a new era in unfair dismissal law in which "economic prosperity"

138 ONS, 'More People in Employment Compared with the Previous Quarter and the Previous Year' (11 September 2013) http://www.ons.gov.uk/ons/rel/lms/labour-market-statistics/september-2013/ sty-employment.html accessed 9 January 2015.

139 Minutes 2014 (n 136) [34].

140 As noted in the Bank of England's Inflation Report August 2014 (n 32).

141 Bank of England, 'Speech Given by Mark Carney, Governor of the Bank of England at the 146th Annual Trades Union Congress, Liverpool' (9 September 2014), 5.

142 The financial penalties provisions for failure to pay sums ordered by employment tribunals contained in the Small Business, Enterprise and Employment Act 2015, c.26 (Royal Assent 30 March 2015) adding ss 37A-37Q to the Employment Tribunals Act 1996) does little to rebalance matters. The Act Bill appears to address the issue of low levels of payment by respondents to employment tribunal awards as outlined in Payment of Tribunal Awards (n 57). 
dominates "social justice" to a degree not seen before'. ${ }^{143}$ With the Coalition changes, labour law has become just a resource for economic recovery.

The long-term implication of this troublingly negative rhetoric about workers is a perpetual call for employment regulation reform which supports economic growth. ${ }^{144}$ While not official government policy, Sir Adrian Beecroft's report spoke to the economic imperative directly. He wrote that the impact of employment reform would be widespread - 'an instant improvement in performance in a significant part of the national workforce'. ${ }^{145}$ He went further to claim that reform is badly needed because only then would the onus be placed on workers to

perform well enough for the employer to value them as workers. It would no longer be possible to coast along, underperforming in a way that is damaging to the enterprise concerned but not bad enough for the employer to want to undertake the whole rigmarole of the unfair dismissal process with its attendant threats of tribunals and discrimination charges. ${ }^{146}$

Consider that the Prime Minister commissioned Sir Adrian's report. This unrelentingly negative perception about the English workforce informs government policy. If the dominant view of workers remains one of widespread lethargy, it would appear that the problem moves beyond employment regulation to something more pervasive requiring attitudinal change. It remains a challenge to see how this situation could be entirely attributable to employment regulation alone, if at all. ${ }^{147}$ Furthermore, it appears as though the rhetoric has outpaced the reality. Part of the argument for toughening employment tribunal access is that 'many claimants who have unfortunately not found a new job have time on their hands and view a free employment tribunal as a no cost option on winning an award'. ${ }^{148}$ A study commissioned by BIS suggested there was little to support such assertions. Only $7 \%$ of claimants had previously made a claim. ${ }^{149}$ Seventy-two per cent of claimants were employed at the time researchers interviewed them. ${ }^{150}$ Fifty-eight per cent of those who had been in work at the time of both launching a claim and interview for the study were earning a similar level to

143 A Sanders, 'Part One of the Employment Act 2008: “Better” Dispute Resolution?' (2009) 38 Industrial Law Journal 30, 31.

144 One Member of Parliament has suggested a dire state for employment in Britain as a result of these changes: 'A low wage, low skill, low morale, low productivity economy is not the right way to proceed.' Michael Meacher (Oldham West and Royton) Hansard HC Deb 12 September 2013, vol 567, col 1247.

145 A Beecroft, Report on Employment Law (London: BIS, 2011), 5.

146 Ibid. The assertion also suggests little confidence in tribunals and courts - another point which lacks merit beyond the bombastic, especially considering low claimant success rates (if one measures tribunal efficiency in this manner).

147 D Mangan 'Employment Tribunal Reforms to Boost the Economy' (2013) 42 Industrial Law Journal 409, 418.

148 Beecroft (n 146) 7.

149 Payment of Tribunal Awards (n 57) 19.

$150 \mathrm{Ibid}, 15$. Fifty-eight per cent were in full-time and $26 \%$ in part-time work: ibid, 17. 
that made before the claim. ${ }^{151}$ In fact, $13 \%$ were working for the same employer at the time of their claim. ${ }^{152}$

Still, the Coalition links employment tribunal reforms with economic growth. To effect this development, emphasis is placed on cutting employment costs such as those related to claims brought by workers or former workers: 'The risk is that the fear of being faced with tribunal claims impedes growth because businesses become too cautious to hire people or to address capability issues in the workforce'. ${ }^{153}$ The current plan takes a singular approach: if claims arise, they should be disposed of before employers are to expend any financial resources.

\section{CONCLUSION}

Duress forms a common theme between the disintegration of collective labour law and the diminution of individual employment protections. The concept of duress was used to connect economic stagnation with employment regulation. Legislation and policy have been utilised to correct this problem. The question as to the actual coercive force of any worker towards her employer chips away at the premise of contemporary government's motivations. It cannot be maintained that now workers who face significant hurdles in even bringing forward an employment rights claim may exert duress on enterprises, and therefore the economy. The unfortunate conclusion that one comes to is that English labour law reforms have aimed to reverse the practical effect of employment protections by organic dissuasion; that is, placing obstacles in the way of bringing a claim forward (despite its merits).

Inevitably, the labour law community returns to the same question: what is labour law about? Recent reforms to access to employment tribunals and the correlating 'disincentives' to bringing a claim impinge upon another central tenet, dispute resolution. The lopsided nature of the present system poses a serious question about not only access but also the future of labour law. The disintegration of employment regulation as offering protection to a full range of workers presaged the reconfiguration of access to dispute resolution. These are by-products of viewing labour law as a support to economic growth. The rising force of the adverse attitude towards employment regulation (and perhaps even talk of enforcing rights) is the most dangerous challenge to access to rights redress.

Ibid, 16. Eighteen per cent were making more than they previously did. However an equal proportion was earning less.

152 Ibid, 17.

153 Progress on Reform (n 85) 24. 